\title{
ARTICLES
}

\section{THE HORIZONS OF POLISH POLITICAL THOUGHT}

\author{
by Michat Śliwa
}

It is not without reason that we reflect more and more on the causes of the current state of political thinking in Polish society. Indeed, in modern times, difficult and uncertain, and turbulent times of great transformation, human thought is clearly not keeping pace. Given the rapidly changing external circumstances we have become increasingly confused and inept. We do not really know how to deal with the emerging threats and challenges of modern times, described by the eminent sociologist and philosopher Zygmunt Bauman as the era of "liquid modernity". It is noticeable that our perception and image of social reality and our role in it, including its political dimension, is quite imperfect and restricted, and that our ideological life is in deep crisis or has perhaps even disappeared.

Therefore, in recent years, the question of whether we, the Poles, have modern political thought has often re-emerged with new strength. Are these ideas shaping contemporary Polish reality? Are they the historyshaping factor? Has there been continuity in the development of Polish political thought in the last two centuries? Have the political elites aspiring to acquire and exercise power reflected, ideologically and intellectually, on the contemporary problems of Poland and the world? What is the future of Polish intellectual and ideological ideas in politics in terms of 
shaping the global policy and global socio-moral order, etc.? Unfortunately, observation of Polish public life does not fill one with optimism. It appears that the actions of politicians, from whom one would expect competent political and ideological reflection and the will to change social reality, are above all, subordinated to electoral tactics and an adequate level of political popularity. The fundamental concepts and principles of organizing political thought, i.e., justice, equality, freedom, dignity, democracy, etc., have almost disappeared from their sight.

Even for the Democratic Left Alliance (SLD, Sojusz Lewicy Demokratycznej), regards itself as a left-wing formation, these constructs are incomprehensible and irrelevant. At its best, it does not pay much attention to them. However, in political practice, growing political inequality and social stratification, high unemployment, poverty and social exclusion, unequal access to cultural goods and education, declining public interest in public affairs and policy, etc., is being accepted.

Virtually all of the country's formations and political parties are barely interested in preventing a crisis of the traditional model of governance resorting to participatory democracy, "survey democracy" or "tabloid democracy", all serving only as democratic dummy devices. Political thought, therefore, did not respond to the challenges and tasks that appeared before the Polish community in connection with the great transformations at the end of the 20th century. Also, it has not developed any new ideas according to the current era, restricting itself only to the ideological and political challenge presented by Poland joining the West.

Meanwhile, the Polish community has entered the sociopolitical transition process in greatly advanced conditions in the world of the globalization processes, heading towards the formation of a single universal civilization. The collapse of real socialism has led to the creation of an ideological vacancy, related to the crisis of leftist thinking and leftist projects, which has meant for many the split of ideology and social life and the decline of ideology, allegedly displaced by increasing religiosity and irrational tendencies.

The forthcoming twenty-first century has been frequently referred to as the Renaissance Era of great religious systems. It did not take long to observe a crisis similar to the aforementioned, that affected the conserv- 
ative-liberal style of political thinking, yet still poorly perceived in the Polish community. Consequently, we have missed the great ideological debate while remaining on the periphery of the developed world, having not taken part in great contemporary debates and political disputes, such as those waged around the future of democracy and market economy, human security the possibilities and limits of human development, etc. This confirms, among other weaknesses, the fallible Polish anti - and alter-globalization movements. Furthermore, the question arises about factors determining the extent and nature of Polish political thinking determinants of the horizon and perspectives. It is not difficult to notice that it is easier for politicians and political journalists to refer to history than to try to seek solutions to urgent problems of modern life and express them in new ideas or previously promoted ones though interpreting them anew. This has been facilitated due to the special attitude of the Poles to the past, considered in terms of the ideological hyper-imperative, defining individual and community identity.

This phenomenon might be explained by the fact that in Poland, a country with long historical periods lacking sovereignty and a conscious sense of national need of subjectivity, the heritage of the past has penetrated strongly and naturally into the present. All the more that the past is not something bounded and closed, but a living, ever-dynamic material. The knowledge of it not only meets important cognitive and social functions, but also culture-developing ones.

It is not at all surprising that this heritage primarily had an impact on the style of Polish political thought, marking its boundaries and areas. Determinants of left-wing or right-wing social and political self-declarations do not arise due to ideological reasons, but from the past. Polish political thinking and its attitudes and behavior are determined by historical ideas and visions, which many years ago, gave rise to the conclusion offered by Jerzy Giedroyc, a careful observer of Polish life, who said that Poland had been ruled, to its detriment, by "two coffins: Piłsudski and Dmowski”. Almost every political movement and ideological or political environment, reborn after the year 1989, eagerly reached to the past claiming to be the natural heir and continuator of the ideological heritage, especially the Second Polish Republic. 
This practice was treated simply as a paradigm of contemporary Polish political correctness and a condition of existence in contemporary Polish consciousness. The most eagerly recoursed tradition was that developed by Piłsudski, in which the figure of Marshal appeals proliferated to the symbol of Polish democracy, the rule of a strong State.

Referring to the Polish tradition on a selective or even instrumental basis, and perceiving it only as a "costume rental", there has been attempts to appropriate and continue it, unfortunately, in the form of a caricature, like it had been done by the Confederation of Independent Poland (KPN, Konfederacja Polski Niepodległej), presently absent from Polish public life. These attempts have similarly been made by all other trends of the Polish tradition with national-democratic and conservative proponents at the helm. As a result, all the weaknesses and negative effects of the interaction and relationships of history and politics have been revealed, similar to other societies.

Perhaps the only formation emergent from political forces of the old regime, the Democratic Left Alliance, situated within left-wing ideological orientation, has been forced to refer carefully to the past due as, among other things, being deemed the historical legitimacy of the Polish tradition of socialist ideas and its other possible references, such as the tradition of the communist tradition, which had been arbitrarily excluded from the national heritage.

Consequently, the characteristic feature of contemporary Polish-style thinking and political practice, incomprehensible to others, is the formation of ideological orientations appropriate to the political balance of power: the ruling party vs. the opposition, that is, the Right against the Right.

Therefore, in general discourse on the construction of ideological alternatives to mainstream Polish political thinking, one does not notice or ignores the debate on social projects and visions of leftist origin and countenance. The Democratic Left Alliance, which had been the most entitled to this by virtue of their political position in society, not only failed to refer to the extremely rich and varied tradition of the socialist, but openly and unambiguously distanced itself from a leftist political thinking style and the manner of leftist politics. 
Additionally, since the very beginning of the restoration of capitalism there has been the idea of separation from its original left-wing ideological labour basis. The notion of the Left is no longer linked with the labour movement - a movement that in its current form has already become extinct. Attempts to renew it, both by the Polish United Workers' Party(PZPR, Polska Zjednoczona Partia Robotnicza) and "Solidarity" (Solidarność) movements have failed. The Polish United Workers' Party has found its continuation rather as a "popular" type of party or Volkspartei, appealing to different social groups, including the middle class. As a result of its anti-socialism program, solidarity and clericalism, "Solidarność" became a right-wing organization. In this situation, what might be considered the final collapse of the political labour movement - which had been autonomous and voluntary, ideologically and politically recognizing the workers as its social basis - took place. Poles have experienced a particular paradox of history: "Solidarność" as a labour movement led to the elimination of the labour movement.

Thus, situations and social phenomena that do not respond to rational and logical description and explanation, which we have become accustomed to describing as Polish paradoxes, have developed. Another example would be the constant search for national identity in the historical tradition of martyrdom, and so the constant recollection of the past, the celebration of national disasters and defeats suffered in modern times.

Numerous political circles even bid against each other in the construction of a martyrologic vision of the most recent history of Poland. The more they use the Homeland-God rhetoric, the more likely they are to legitimize Polish reality. Of course, the formations and the groups who define themselves as conservative and national-Catholic, though often ephemeral and sofa-bound, dominate the scene. The favorable factor for the above-mentioned formations would be, inter alia, to discredit one of the socialist projection - real socialism, and the revival of the nationalist movements in different regions of the world in response to the intensification of globalization and the emerging controversy over Polish aspirations of integration with the European Communities, which again the national right-wing environments aim to use to complete the PolishCatholic mission against the liberal and secular West. They direct the 
attack especially against their competitors proclaiming a universalist political vision of social order, to allegedly threaten national homelife and even lead to the collapse of the nation. The Polish ideological Left, which is in search of a new identity, is particularly under attack in the form of negation and criticism.

In order to undermine its position in society, the Left is preferably accused of its antipatriotic attitude or even a betrayal of national interests and servitude to foreign policy in the past. It is facilitated due to the fact that in the past, accusations of leftist national apostasy have been the most frequently appearing argument since the first traces of socialist ideas in Polish culture. Furthermore, since the thirties of the nineteenth century, this has been even more salient as anti-socialist literature undoubtedly forms a considerable amount of ideological and propaganda work.

Therefore, today the practice of denying the fact that leftist formations in Poland have been patriotic and national is a paradoxical phenomenon of common scale. The fact that the Polish right-wing environment has established a monopoly on patriotism and independence has not turned out well for Polish political life, as contemporary Polish disputes and problems are noticeably distorted. Attempts are made to limit them to a reply to one question: Whose Poland is it? Indeed, issues concerning the modernization of the country, civilizational advancement of society, development of national culture, etc., should not to be the subject of debate, but rather narrowly understood problems and arbitrarily interpreted merits in the task of preserving a sense of patriotism and the recovery of complete national sovereignty. Consequently, recent history is becoming a fierce political battlefield, which has only to provide positive or negative models legitimizing the present reality. However, it is often forgotten that its variability induces the need for variability of legitimacy of changing patterns, which again disputes the validity of the entire legitimizing mechanism as it may serve to justify everything. In this way, having subordinated the current arguments and policy needs to the past it has deformed the image of history, mythologized the historical consciousness of society and distorted political thought, defining its conceptual framework through the prism of the awkwardly reinterpreted past. Expectedly, nowadays there are attempts to strengthen, in every way, the 
public belief that the conflicts and divisions in Poland have a different nature than those in other European countries, since they are centered around national values explicitly neglected and even deliberately destroyed by the Left in the past. In this situation, for the contemporary Polish rightwing, left-wing constitutional formations cannot even be understood nor accepted, furthermore negating the belief in the need and the possibility of a change in social reality and adapting it to human aspirations and thus solving the great problems of the experienced era.

A modern Pole cannot contemplate the essence of leftism nor attempt to define it, contrary to the French, German or English, who can do it under any conditions and without any obstacles. Still, there are many issues to reflect upon and to redefine, even the fact that a significant part of society - as a result of experiences in the restoration of the capitalist order - has begun to doubt the efficiency of free market mechanisms and is disappointed with neo-liberal problem-solving. The leftist faces the dilemma of whether the left wing means only the pursuit of modification of capitalism by developing it into a "human" dimension or it reaches beyond the horizon of capitalist system transformations. The low efficiency of democratic devices and procedures, and the growing phenomenon of the democratic deficit at the local and national level is a cause of concern. It turns out that the will of the voters might not always or completely be accomplished, since different restrictions, e.g., economic or global policy requirements may become an obstacle.

Unfortunately, for the contemporary leftist in Poland, these cannot be problems of prime importance. After all, what counts above all is its "illegitimate" origin, particularly the one of its main formation - the Democratic Left Alliance. Being charged with all the transgressions in the yet recent past, and still held responsible for the sins of real socialism, both committed and not committed, and therefore assigned to a place in the "dustbin of history", it is appealing constantly, with varying degrees of intensity, to reconciliation with the past - through lustration and decommunization. One does not want to see that real socialism was not the only legitimate and necessary project of the socialist social order, and that the socialist ideas in the plans for transforming the political and constitutional projections are subject to various interpretations and 
modifications and incorporate potentially different types of organizations in society. The fact that real socialism has failed does not mean the defeat and the end of the socialist idea in general. Democratic socialism, for example, whose role in the task of modernizing societies in Western countries today is not to be disputed, has dimensions, other than the ideological and practical, from of Communist totalitarianism. Real socialism collapsed, but the problems with which it attempted to deal remain, having returned with renewed strength. Despite right-wing forces having made the appropriately prepared past the most important factor constituting national identity, the patriotic and moral imperative, it did not prevent them from opting for a neoliberal model of economic governance, naturally promoting globalist solutions, and thus assuming the unification of cultures and reducing the nation-state sovereignty. It has obscured many social and cultural issues and prevented public debate over them. Despite its failure in the modern world under the influence of the economic and financial crises being experienced, it has continued to be the primary factor determining people's attitudes and the frame of political discourse in Poland. It has strongly penetrated Polish consciousness, especially to the awareness of the main political elites, and any attempt to renew Polish political thinking and giving it a modern ideological form were unsuccessful through the dissolution of the circle of neoliberal axioms. Born out of the working-class rebellion in August, with a socialist background, the vision of the new socio-economic "Self-governed Commonwealth" was soon replaced by epigones - bourgeois reconstructions of capitalism with an Anglo-Saxon face.

After the June 1989 victory, a radical political turn had occurred and the procedure of restoration of the most unjust socio-economic system in the history of postwar Europe immediately began. Skeptical voices questioned the meaning of neoliberal economic policy and undermined confidence in the free market economy as the foremost instrument of governance system restructuring. Criticism stating that the reconstruction of the market economy is a long process and that it is impossible to realize in a few months or years as this leads to chaos, entails high social costs and causes the demoralization of society, was not accepted. Neither were the obvious warnings of what the implementation of a neoliberal option 
system transformation would cause; a sharp increase in unemployment and poverty on an unprecedented scale the deepening of income inequality and social inequality in general, a massive economic emigration, the buildup of conflict in relations between employer and employee, the expansion of large numbers of people excluded socially and culturally, etc.. An entire twenty years of experience was necessary to see the merits of a skeptical attitude to the political transformation of neoliberal character. Throughout that time the neo-liberal paradigm constituted certain ideological and political taboos, and though sentenced to failure, there had been attempts to undermine and criticize them, though now the critical assessment is penetrating public opinion more and more boldly and is listened to attentively. Yet only recently, while there were attempts to conceal the ideas of economic freedom by cultural conservatism, it is already today that there are increasingly frequent claims for a more active role of the State in the economic sphere and "liberalization" of cultural traditionalism.

The phenomenon of dominance of the neoliberal paradigm in Polish political thinking most likely resulted not only from the need to overcome the economic system of real socialism, but also from the pursuit, perhaps more significant among the political elite than among society itself, to break the existing ties with the East (Russia), seen as foreign to Poland and violently imposed on it. In that new situation, in spite of adversity, the Poles were to be perceived as being consistently at western-style economical positions. At the same time, their return to the European identity was to mean "neo-liberalization" of the Polish world of values and ideas.

The place of the hitherto ally and the guarantor of the development of Polish culture and progress of civilization, formerly the East (Russia), has been taken by the West now, and according to a substantial part of Polish opinion, by the United States of America in particular. The adoption of more western-style economy options, meaning Westernization of Polish life, have resulted in a way which had not been expected, i.e., as a triumph of neo-liberalism in Polish politics. This had a negative impact on the development of Polish political thought, as the paradigm of neo-liberalism, inter alia, repudiated the progressively weakening politically correct liberalism, which has always had problems with its political self-organization. 
The post-Communist Left has also surrendered to it, especially when it remained at the helm of state power, immediately abandoning the previously declared leftist ideas in favor of neoliberal policies. Such proceedings were explained as compensation for the errors committed in the past that had not been opposed to the use of "instruments deforming and weakening the actions of the market mechanism". At the same time, actions to back up the escalation of economic growth and the strengthening of a free market economy as the basis for national development within the European Union have been supported. The ideological and political ideas of that left, lacking a place for reflection typical of left-wing environments as expressed in skepticism, inter alia, in the attitude towards the neo-liberal belief in unlimited growth and unlimited opportunities for human development.

Consequently, there has been an unnoticed need not only for a reflection on the general problems of civilization and its consequences for Polish society, but also to avoid taking any ideological and political thought on the very burning issues of the country: social security and national health, social and cultural degradation of numerous groups of the population as a result of a neoliberal system transformation, modernization and reconstruction of agrarian relations and national economy, democratization of the society and the construction of a modern social order in Poland, etc. Thus, Polish society still does not have a clear vision of systemic order based on appropriately modified capitalism through pro-social activities of the democratic state.

There is also no alternative to this mainstream Polish political thought on the part of various visions and social projects, often described as "third way", developed with considerable success in the past, for example by the Christian democratic movement.

Although there were attempts to construct a system of corporatism or "popular capitalism" with their respective terms - social solidarity, personalism, the principle of subsidiarity, social justice and the common good, fair wages and fair profits, diffused ownership and employee share ownership, and united Europe as "the Europe of homelands" - they did not go beyond vague slogans and were not submitted in a coherent sociopolitical doctrine. 
This only confirms the exceptional weakness of the Christian democratic movement, in fact, its absence in the period of political transformation in Poland, a country with the Catholic Church in a dominant position and the vast majority of the population being Catholic. Which explains, among other things, this exceptional situation of the Catholic Church which, without any effort and without indirect devices, applies to public opinion and immediately implements the demands of the Christians in politics, public life and state.

The more that Christian ethics and Catholic social teachings relate, though frequently it may be only verbally, many conservative groups, nationalist and popular, even liberal and many more, are open to Christian values. A positive attitude to the Catholic Church and its sociomoral tradition has already become of paramount importance for the Polish ideological and artistic center. It provides a sort of ideological paradigm and even the condition of social acceptance. The Church hierarchy was able to use it to its own advantage. Having already had a historically and culturally established position in Polish society, the Church has strengthened it further due to constant contestation of the system of real socialism and by supporting every opposition against it, including the leftist opposition. Therefore from the start of political changes it came out augmented in power, exerting strong influence on the formation of Polish public life and the Polish political scene. The politicization of the institution of the Church and its hierarchy has taken place on an unprecedented scale, despite its constant alleged declarations that the church cannot be engaged in political life and does not aspire to exercise power in the state. Though, having to comply to an appropriate mission in society, the Church could not remain indifferent to social and political issues and does not surrender as the representative of the national-religious community in formulating goals and sociopolitical tasks and monitoring their implementation.

As a result, the Church has achieved a significant political influence, causing its desired transformation of the Polish political scene, especially on her right and centrist pole, though its left part, including the postcommunist left, is also not free from its impact. In this new Polish reality it has been considered as the initiator and the guarantor of the democratic transition, though remaining exceptionally hierarchical and autocratic in 
structure. It distanced itself from the dialogue and cooperation with the democratic left of the anti-communist opposition era, and returned to the traditional perception - as it did in the first half of the twentieth century to its allies and supporters in conservative and national-Catholic circles. At the same time, it was not interested in the reconstruction and development of the previously mentioned Christian democratic movement.

Consequently, the Polish political and ideological space has taken almost a religious dimension, especially in the context of the right-left dyad. The more that people who identify with the first political formations demonstrate towards their left wing adversaries, who require discussion on the place and role of the Church in society and the country to limit its influence, a higher level of religiosity and support for the Church occurs. This certainly favors the strengthening of ties and cooperation between the Church and right-wing environments, but also hinders any debate about its situation in public life and on the socially and culturally crucial problems of the contemporary era. All the above result in the immaturity and superficiality of Polish political and ideological reflections. This distinct weakness and uncertainty is presented particularly by the centerleftist orientation, though does not mean that the other political currents of thought respond to the challenges and needs of the present, and may, at least potentially influence and shape Polish relations. None of the conservative, liberal or nationalist ideas coherently nor comprehensively reflect a vision or a project-to-measure of the social order for the experienced period of history. For instance, the Popular in a number of political groupings with conservative ideas, or rather conservative-liberal ideas, are not modern in character, at least in the form of vivid British "Thatcherism" or American "Reaganomics" many years ago. They are greatly diversified and differ significantly from their prototypes, in a fairly arbitrary way taking over their ideological and doctrinal assumptions. Therefore, they have currently questioned, perhaps under the influence of negative experiences of an Authoritarian state from the period of real socialism strongly rooted in the tradition of Polish conservatism, the visions of the state as the superior value and common good. They rather promote a model of a state with restricted functions and a subordinate role towards society, although among them there are considerable differ- 
ences in opinions on the structure of the political state and mutual relations between politics and economy. Similarly, liberal ideas are insufficiently clear. They have a unilateral and distorted character. Focusing primarily on the economic issues and carefully omitting ideological issues and freedom of the individual, they are more like the ideas of liberism or libertarianism. The state of contemporary Polish nationalist thought is not on any better condition. It is also strongly differentiated ideologically and doctrinally, especially as it concerns the model of political system, the Polish postwar history, the manner of achieving national goals, etc. It proclaims a populist economic program and does not avoid the "Catholicization" of the Polish nationalism.

Given this, it is no wonder that advocates faithful to keeping the Polish national-democratic tradition of the circle of the former Christian National Union (ZChN, Zjednoczenie Chrześcijańsko-Narodowe) denied the latest emanation of the nationalist movement - the League of Polish Families (LPR, Liga Polskich Rodzin) the right to the renewal of the ideological heritage of Roman Dmowski, calling them a typically populist formation, which could not last even a single political season. On the outskirts of conservatism and nationalism, negative judgments of the post - transformative Polish reality are constantly emerging - visions of Poland appearing as a dependent country, even under the Brussels-Berlin-Moscow occupation, at head of which stands not a democratically elected president, but a "resident", and the Country being governed according to the Bolshevik model by the Civic Platform (PO, Platforma Obywatelska), i.e. by the "POlshevic". However, the most appropriate way to change the situation of Polish society is to establish, on conservative-nationalist political ground, an authoritarian model of state power and the restoration of full national sovereignty. Under the influence of the strong interaction of peculiarly understood paradigms - historism, neo-liberalism and Catholicism - Polish political thought had been distorted and dogmatized. It has become outdated and lacks a response to contemporary problems and civilizational and cultural challenges. It does not provide a natural continuation of the democratic current in the development of twentiethcentury political thought. 